\title{
DETERMINANTS OF JOB SATISFACTION AMONGST EMPLOYEES IN THE POULTRY SUB-SECTOR OF GHANA: A TEST OF EQUITY THEORY
}

\author{
Edward Yeboah ${ }^{4}$, Anthony Donkor ${ }^{5}$ \\ Science and Technology (KNUST), Kumasi, Ghana. \\ nicholas.mensah@uner.edu.gh \\ ernestchristliebamrago@yahoo.com \\ kasare14@gmail.com \\ eddie.yeboah401@gmail.com \\ anthony.donkor@uner.edu.gh
}

Nicholas Oppong Mensah ${ }^{1}$, Ernest Christlieb Amrago' ${ }^{2}$ Jeffery Kofi Asare ${ }^{3}$,

${ }^{1,2,3}$ School of Agriculture and Technology, Department of Agricultural Economics, Agribusiness, and Extension, University of Energy and Natural Resources (UENR), Sunyani, Ghana.

${ }^{4}$ Department of Accounting and Finance, KNUST School of Business, Kwame Nkrumah University of

${ }^{5}$ School of Agriculture and Technology, Department of Agricultural Economics, Agribusiness, and Extension, University of Energy and Natural Resources (UENR), Sunyani, Ghana.

\begin{abstract}
The study investigated the factors affecting job satisfaction amongst workers of the poultry sub-sector: a test of equity theory in the Dormaa Municipality in the Bono Region of Ghana. The multistage sampling technique was employed in collecting data from 100 poultry workers with the aid of a structured questionnaire. The logit model was employed in modeling the factors affecting job satisfaction. The empirical findings reveal that occupational level, pay, and relationships with co-workers were the statistically significant determinants of job satisfaction. Moreover, the study found that based on equity theory if poultry workers are satisfied with their pay, they would want to stay longer compared to referent others who are not satisfied. Benevolent poultry workers were dominant (52\%), followed by equity sensitive (28\%) and entitled (20\%) poultry workers. Moving forward, the relevance of equity theory on workers in the cocoa value chain should also be investigated as cocoa remains a staple crop in Ghana.
\end{abstract}

Keywords: Equity Theory, Job Satisfaction, Poultry Sector, and Working Environment (JEL Code: Q10)

\section{INTRODUCTION}

The issue of what propels employees have called for more research in organizational behavior in the past 5 decades (Bolino and Turnley, 2008). As such, in the 1960s works on equity theory became eminent (Allen et al. 2005). However, equity could be substituted with inequity (Adams, 1963). Hence, Adams, (1963) propounded that a state of inequity exists when a person perceives that his input-outcome is not in line with the input-outcome of referent other. Besides an employee becoming satisfied with his job will depend on this input-outcome comparison. After the comparison is made the employee feels motivated to expend his time and effort in the organization if only he is equitably rewarded but if the comparison is otherwise he becomes dissatisfied with the work (Kingsley Westerman et al. 2007; Dugguh and Dennis, 2014). As a consequence, the state of inequity would culminate in high job dissatisfaction and dissonance (Kollmann et al. 2019). Accordingly, Allen and White, (2002) explained that dissatisfied workers as a result of the under-reward situations have several ways of ensuring their input-outcome is balanced. Therefore, according to Walster et al. as cited in Lapidus and Pinkerton, (1995) an employee could balance the input-outcome ratio by making alterations to his or her inputs or seek a pay increase (outcome), or comparing himself to a lower referent other to reduce sentiments of inequity, as well, the employee could resign from the organization. In consequence, it is worth noting that other current and extant works have extended equity theory into 
equity sensitivity (Mudrack et al. 1999; Allen et al. 2011; Oren and Littman-Ovadia, 2013) by categorizing employees into three distinct groups thus, benevolent, equity sensitive's, and entitled. Employees categorized as benevolent have the tenacity to work under conditions of low-reward whereas entitled employees demonstrate poor toleration to low-reward and would always fight for high-reward (Aggarwal and Bhargava, 2010). However, equity sensitive employees neither strive for over-reward nor tolerate under-reward, instead, they prefer a reward (outcome) commensurate to their input. Besides, worldwide several studies have been conducted on equity theory (Kingsley Westerman, 2013; Van Mourik, 2014; Lovegrove \& Fairley, 2017). Despite the growing body of literature on equity theory, in Ghana and beyond no empirical study has examined the factors affecting job satisfaction amongst employees in the poultry sub-sector: a test of equity theory. This paper, therefore, seeks to address the research gap. Against this backdrop, it is indispensable to test equity theory on job satisfaction amongst workers in the poultry sub-sector, specifically Dormaa Municipality. The study highlights the relevance of equity theory on job satisfaction.

\section{MATERIALS AND METHODS}

\section{Study area}

Dormaa Municipality is situated in the western sector of the Bono and Ahafo Region. The municipality has an undulating topography that hikes beyond sea level between 180 meters and 375 meters (GSS, 2014). Since time immemorial, the area has been recognized as the leading producer of poultry products (Spent layers, broilers, and eggs) (Bannor et al. 2020). Therefore, making the economically active populace to consider the production of poultry as the main economic activity. Aside from poultry production, the cultivation of crops such as maize, vegetables, cocoa, and cashew dominates the municipality. Figure 1, show details on the area of study:

Figure 1: Map of Dormaa Municipality

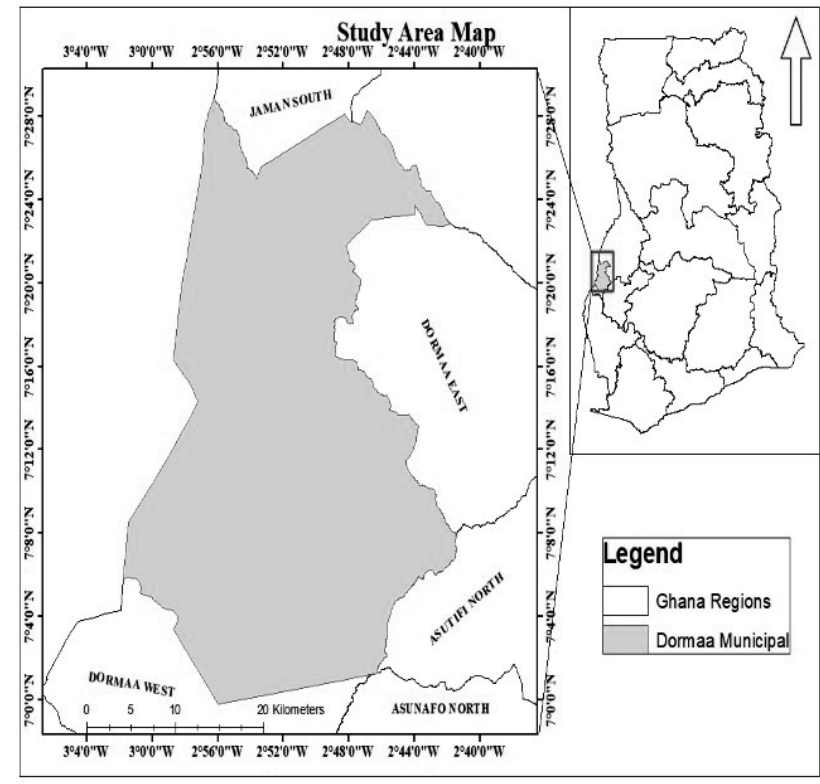

Source: Author's Construct, 2020

\section{Hypothesis for the study}

According to Amissah et al. (2016), pay is a significant determinant of job satisfaction amongst employees in the hotel industry of Ghana. Likewise, in Northern Cyprus pay had a significant positive effect on job satisfaction amongst frontline workers in the hotel industry (Karatepe et al. 2003). Given the significance of pay to job satisfaction, we assume that pay could influence a poultry worker to stay or leave the organization after comparing his pay to a referent other in a similar organization. Therefore, the following hypothesis is proposed:

$\mathrm{H}_{0}$ : Based on equity theory, if poultry workers are satisfied with their pay, they would not want to stay longer compared to referent others who are not satisfied.

Ha: Based on equity theory, if poultry workers are satisfied with their pay, they would want to stay longer compared to referent others who are not satisfied.

\section{Sampling technique and sample size}

The multistage sampling procedure was adopted in this study. Firstly, Dormaa Municipal was purposively selected on the account of the predominance of poultry farmers (Mensah et al. 2020). Secondly, three communities, namely, Aboabo No.1, Kofi Asua, and Atesikrom were selected purposively as a result of the immense engagement in poultry farming. Thirdly, a list of poultry workers sourced from the Dormaa Poultry Farmers Association was used to randomly sample 100 poultry workers for the study. Purposely to give the respondent a fair chance of being included in the sample (Taherdoost, 2016). Although the sample size is relatively small it satisfies the central limit theorem. This states that a sample size $\geq 30$ is appropriate for a standard normal distribution because as $\mathrm{n}$ (sample size) increases, the standard deviation decreases. Notably, in this case, the total population of poultry workers in the study area was not readily available and in so doing the sample size of 100 poultry workers was good for analysis. Moreover, 500 registered poultry workers were in the records of the Dormaa Poultry Farmers Association during the interview, yet currently, the poultry workers are around 700. As a result, should the approach of Yamane (1967) for determination of sample size be adopted (margin of error at $10 \%$, roughly 83 poultry workers would represent the target population) indicating that the sample size of 100 poultry workers is suitable? Besides, a qualitative and quantitative research design was deployed in the study.

Concerning data collection, a period of two months (15th January -15th March 2020) was used. After pre-testing of the survey instrument, field assistants were trained on the effective administration of the instrument to aid reduce response errors to the barest minimum. The instrument covered socio-economic data, such as age, gender, educational level, years of experience, marital status, and off-farm job. The factors affecting job satisfaction included, pay, supervision, 
job content, relationship with co-workers, promotion, and occupational level.

\section{Logit model}

This paper proposes that the decision to be satisfied with the job or otherwise is dependent on the utility that a poultry worker gets from working at the poultry farm. As a result, in the case of modeling, dichotomous variables the logit and probit models are employed (Hoetker, 2007).

The paper, presumes that the decision of a poultry worker to be satisfied with the job or not satisfied with the job is contingent on a utility index that is unobservable $\mathrm{I} * \mathrm{i}$, and depends on explanatory variables such as supervision, pay, job content, and relationship with co-workers. The index is expressed as:

$$
\mathrm{Q}_{\mathrm{I}}^{*}=\beta \mathrm{x}+\varepsilon_{\mathrm{i}}
$$

Where $i=i$ th poultry worker, $\varepsilon=$ Error term, and $\beta=$ Coefficient of the explanatory variables $x=$ Explanatory variables.

However, the index that is unobservable is related to the genuine decision of being satisfied with the job or not being satisfied with the job by plausibly presuming that:

$\mathrm{Zi}=1$ (a poultry worker is job satisfied) if $\mathrm{Q} * \mathrm{i} \geq 0$

$\mathrm{Zi}=0$ (a poultry worker is otherwise of the job) if $\mathrm{Q} * \mathrm{i} \leq 0$

Thus, should a poultry worker's index utility I go beyond the level $Q^{*}$, the worker would be satisfied but if it is less than $Q^{*}$, that poultry worker will not be satisfied.

Making the decision operational, we presume that the probability to make a decision, thus the choice of being job satisfied (That is: $Z=1$ ):

$$
\begin{aligned}
& \operatorname{Pr}\left(Z_{\mathrm{i}}=1\right)=\operatorname{Pr}\left(\mathrm{Q}^{*} \geq 0\right) \\
= & \operatorname{Pr}\left[\left(\beta \mathrm{x}+\varepsilon_{\mathrm{i}}\right) \geq 0\right] \\
= & \operatorname{Pr}\left(\varepsilon_{\mathrm{i}} \geq-\beta \mathrm{x}\right)
\end{aligned}
$$

The probability is contingent on the $\mathrm{Zi}$ probability distribution and in turn, depends on the error term, $\varepsilon$ i probability distribution. Should the probability distribution be uniform throughout (zero) mean, then Eqn. 2 is expressed as:

$$
\operatorname{Pr}\left(\varepsilon_{\mathrm{i}} \geq-\beta \mathrm{x}\right)=\mathrm{P}\left(\varepsilon_{\mathrm{i}} \leq \beta \mathrm{x}\right)
$$

Hence,

$$
\mathrm{P}_{\mathrm{i}}=\operatorname{Pr}\left(\mathrm{Z}_{\mathrm{i}}=1\right)=\operatorname{Pr}\left(\varepsilon_{\mathrm{i}} \leq \beta \mathrm{x}\right)
$$

$P_{i}$ is contingent on a specific probability distribution of $\varepsilon_{i}$.

The model presumes that the probability distribution of $\varepsilon_{i}$ follows the probability of the logit distribution, in our case, written as:

$$
P_{i}=\frac{1}{1+e^{-Z_{i}}} \quad \frac{P_{i}}{1-P_{i}}
$$

Where $P_{i}=$ probability of job satisfaction (That is: $Z_{i}=1$ ) and

$$
Q_{i}=\beta x+\varepsilon_{i}
$$

The probability that $Z=0$, (i.e. the worker is not satisfied with the job), is given by

$$
1-P_{i}=\frac{1}{1+e^{Z_{i}}}
$$

The probability that the worker is job satisfied against the probability that the worker is not satisfied with the job is expressed as:

$$
\frac{P_{i}}{1-P_{i}}=\frac{1+e^{Z_{i}}}{1+e^{Z_{i}}}=e^{Z_{i}}
$$

Where, $\frac{P_{i}}{1-P_{i}}=$ Odds ratio in favor of being satisfied with the job: the ratio of the probability that the poultry worker is job satisfied with the probability that the poultry worker is not satisfied with the job.

Natural logarithm of equation (8), specifies the logit model as:

$$
L_{i}=\operatorname{In}\left(\frac{P_{i}}{1-P_{i}}\right)=Z_{i}=\beta \mathrm{x}+\varepsilon_{i}
$$

The empirical model is specified as:

$1 n\left(\frac{P}{1-P}\right)=\beta o+\beta 1$ Age $+\beta 2$ Education $+\beta 3$ Experience $+\beta 4$ Marital Status $+\beta 5$ Occupational level $+\beta 6$ Pay + $\beta 7$ Supervision $+\beta 8$ Job content $+\beta 9$ Relationship with coworkers $+\beta 10$ Promotion $+\varepsilon_{\mathrm{i}}$

Table 1, shows the variables used in the logistic regression analysis. 10 variables were employed in the analysis. These variables were subjected to two main sub-headings, particularly, poultry worker characteristics and farm characteristics. Job satisfaction was the dependent variable for the study. It is instructive to note that, promotion, relationship with coworkers, job content, supervision, pay, occupational level, and education was expected to positively influence job satisfaction. Nonetheless, Age, experience, and marital status were hypothesized to negatively influence job satisfaction.

Further, from Table 1, the average age for the poultry workers interviewed was 27 years. Again, the mean number of years the poultry worker had being educated is approximately 13 years, which implies that the majority of the poultry workers had gained secondary school education. The average experience of roughly 4 years was gained by the poultry workers. The mean value of 0.21 indicates that the majority of the poultry workers were not married. Besides, the occupational level for the poultry workers was low with a mean value of 0.27 . The mean pay for the poultry workers was approximately Ghc 129.00 (US dollars 22.00) per month. The supervision of the poultry workers was bad (0.20). Likewise, job content was also bad, hence a mean value of 0.52 . Relationships with co-workers and promotions were poor with an average value of 0.54 and 0.83 respectively. 
Table 1: Description of Independent Variables Used in the Binary Logistic Regression

\begin{tabular}{|c|c|c|c|c|c|c|}
\hline Variable & Description & Measurement & Expected sign & Mean & Std. Dev & Relevant literature \\
\hline Dependent variable & Job satisfaction by poultry workers & $1=$ Satisfied & & & & \\
\hline Job satisfaction & & $0=$ Otherwise & & 0.47 & 0.50 & \\
\hline \multicolumn{7}{|l|}{ Independent variables } \\
\hline \multicolumn{7}{|l|}{$\begin{array}{l}\text { Demographic } \\
\text { characteristics }\end{array}$} \\
\hline Age & Age of the respondent & Number & - & 27.38 & 6.92 & Bender \& Heywood, (2006) \\
\hline Education & $\begin{array}{c}\text { Highest } \\
\text { Educational level }\end{array}$ & $\begin{array}{l}\text { Number of years } \\
\text { in school }\end{array}$ & + & 12.76 & 1.86 & Metle, (2001) \\
\hline Experience & $\begin{array}{c}\text { Number of years in poultry } \\
\text { farming }\end{array}$ & Number & - & 3.74 & 1.32 & Artz, (2010) \\
\hline Marital status & Marital status of respondent & $\begin{array}{c}1=\text { Married } \\
0=\text { Otherwise }\end{array}$ & - & 0.21 & 0.41 & Tarcan et al. (2017) \\
\hline Occupational level & Highest occupational level attained & $\begin{array}{l}1=\text { High } \\
0=\text { Low }\end{array}$ & + & 0.27 & 0.45 & Oshagbemi, (2003) \\
\hline \multicolumn{7}{|l|}{ Farm characteristics } \\
\hline Pay & Salary of the poultry worker & Ghana Cedis & + & 128.90 & 30.48 & Ellickson \& Logsdon, (2002) \\
\hline Supervision & Poultry worker level of supervision & $\begin{array}{c}1=\text { Good } \\
0=\text { Bad }\end{array}$ & + & 0.20 & 0.40 & Rana \& Agrawal, (2016) \\
\hline Job content & Job content of respondent & $\begin{array}{c}1=\text { Good } \\
0=\text { Bad }\end{array}$ & + & 0.52 & 0.50 & Rana \& Agrawal, (2016) \\
\hline $\begin{array}{l}\text { Relationships with co- } \\
\text { workers }\end{array}$ & $\begin{array}{l}\text { Good relationships with co- } \\
\text { workers }\end{array}$ & $\begin{array}{l}1=\text { Yes } \\
0=\text { No }\end{array}$ & + & 0.54 & 0.50 & Čábelková et al. (2015). \\
\hline Promotion & $\begin{array}{l}\text { Poultry worker received a } \\
\text { promotion }\end{array}$ & $\begin{array}{l}1=\text { Yes } \\
0=\text { No }\end{array}$ & + & 0.83 & 0.38 & Tinuoye et al. (2016) \\
\hline
\end{tabular}

Source(s): Author's Construct, based on field data and literature review, 2020. NB: 1 US dollar = Ghc 5.80

\section{RESULTS AND DISCUSSION}

Table 2: Socio-Demographic Characteristics of Respondents

\begin{tabular}{|c|c|c|}
\hline Variable & Frequency & Percentage (\%) \\
\hline \multicolumn{3}{|l|}{ Age } \\
\hline $10-19$ & 7 & 14 \\
\hline $20-29$ & 31 & 62 \\
\hline $30-39$ & 8 & 16 \\
\hline $40-49$ & 3 & 6 \\
\hline $50-59$ & 1 & 2 \\
\hline \multicolumn{3}{|l|}{ Gender } \\
\hline Male & 43 & 86 \\
\hline Female & 7 & 14 \\
\hline \multicolumn{3}{|c|}{ Educational Level } \\
\hline None & 7 & 14 \\
\hline Basic & 15 & 30 \\
\hline Secondary & 26 & 52 \\
\hline Tertiary & 2 & 4 \\
\hline \multicolumn{3}{|c|}{ Years of Experience } \\
\hline 1-11months & 16 & 32 \\
\hline $1-5 \mathrm{yrs}$ & 26 & 52 \\
\hline $6-10 \mathrm{yrs}$ & 5 & 10 \\
\hline$>10 \mathrm{yrs}$ & 3 & 6 \\
\hline \multicolumn{3}{|c|}{ Marital Status } \\
\hline Single & 33 & 66 \\
\hline Married & 17 & 34 \\
\hline \multicolumn{3}{|c|}{ Off-Farm Job } \\
\hline Yes & 32 & 64 \\
\hline No & 18 & 36 \\
\hline
\end{tabular}

Source: Field Survey, 2020
From Table 2, The distribution of age shows that most (62\%) of the poultry workers were within the age range of 20-29 years. Indicating a youthful dominance in the poultry sub-sector. Hence, the poultry workers in the study area are economically active. Accordingly, GSS, (2014) reported that individuals within the age bracket of 15-64 are active economically. Further, the result reveals that males $(86 \%)$ predominate the poultry industry in the study area. Perhaps males are physically strong and active to engage in productive roles, while females are engaged in reproductive roles that attract fewer rewards unless the females are household heads. This phenomenon in the poultry sub-sector is consistent with Owusu-Sekyere, (2011) who revealed that poultry activities are carried out by males. Considering the educational level, $14 \%$ of the poultry workers had no formal education while the other workers had formal education between basic, secondary, and tertiary levels. These results could be based on the extensive use of manual or computerized bookkeeping system in the poultry industry (Amoabeng, 2011). Most of the poultry workers (52\%) have experienced between 1 to 5 years with $32 \%, 10 \%$, and $6 \%$ of the poultry workers having 1-11 months experience, 6-10 years of experience, and more than 10 years of experience respectively. Intrinsically, the considerable years of experience of the poultry workers in the poultry industry have a good prospect for the poultry sub-sector. From the results, $66 \%$ of the poultry workers were not married whereas $34 \%$ were married. Besides, the propensity of the unmarried poultry workers expending their pay on a household is low because they are still in their youthful age and not prepared for marriage. A total of $64 \%$ of the poultry workers affirmed that they have other jobs aside from the poultry work. These jobs included 
being a mechanic, mason, and washing of clothes for some households as their secondary occupation. However, aside from the poultry work, $36 \%$ of the poultry workers indicated they have no other job.

Table 3: Logit Model Estimates of Factors Influencing Job Satisfaction

\begin{tabular}{|c|c|c|c|}
\hline & \multirow[b]{2}{*}{ Coefficient } & \multicolumn{2}{|c|}{ Logit Regression } \\
\hline & & Standard Error & $\begin{array}{c}\text { Marginal } \\
\text { Effect }\end{array}$ \\
\hline \multicolumn{4}{|l|}{$\begin{array}{l}\text { Poultry worker } \\
\text { characteristics }\end{array}$} \\
\hline Age & -0.0277 & $(0.0329)$ & -0.0069 \\
\hline Education & 0.0983 & $(0.1397)$ & 0.0244 \\
\hline Experience & 0.3461 & $(0.1980)$ & 0.0860 \\
\hline Marital status & 0.1111 & $(0.6035)$ & 0.0276 \\
\hline Occupational level & $-1.3708^{* *}$ & $(0.6258)$ & -0.3407 \\
\hline \multicolumn{4}{|l|}{ Farm characteristics } \\
\hline Pay & $-0.0293 * * *$ & $(0.0099)$ & -0.0073 \\
\hline Supervision & -0.5540 & $(0.6339)$ & -0.1377 \\
\hline Job content & 0.5455 & $(0.6138)$ & 0.1356 \\
\hline $\begin{array}{l}\text { Relationships with } \\
\text { co-workers }\end{array}$ & $1.4866^{* *}$ & $(0.6314)$ & 0.3695 \\
\hline Promotion & -0.1712 & $(0.7282)$ & -0.0426 \\
\hline Prob $>$ Chi2 & $0.0030 * * *$ & & \\
\hline Pseudo R2 & 0.1926 & & \\
\hline Log-likelihood logit & -55.8170 & & \\
\hline LR Chi2 (10) & 26.64 & & \\
\hline
\end{tabular}

From Table 3, the likelihood ratio statistic (LR) of 26.64 with 10 degree of freedom is statistically significant at $1 \%$. Indicating that some of the factors affect job satisfaction. Consequently, age, education, experience, marital status, supervision, job content, and promotion have no statistically significant impact on job satisfaction. However, occupational level, pay, and relationships with co-workers were statistically significant factors influencing job satisfaction. In the study, the occupational level is negative and significant $(\mathrm{p}<0.05)$. This indicates that as the poultry worker increases in occupational level at the poultry farm the probability that he will be satisfied with the job is more likely to decrease by $34 \%$. This is because, as his position at the job changes to a higher level, more tasks which are daunting, laborious, and herculean are assigned to him, however, work at the poultry farm is not easy it requires the economically active to be able to accomplish the task. In consequence, the poultry worker who has just experienced a change in occupational level becomes dissatisfied at the job. This result contradicts the study of Oshagbemi, (2003) who found a positive association between academic rank and job satisfaction. However, the result is consistent with Lee et al. (1981) that the occupational level was an important determinant of poultry worker's job satisfaction.

The pay was negative and significant $(\mathrm{p}<1 \%)$. Implying that, an increase in the payment of salary to the poultry workers is likely to decrease their satisfaction at the job by $73 \%$. This could be attributed to the fact that the salary of the poultry workers is relatively small, and if there is any pay rise it increases by a marginal amount which stifles the entrepreneurial behavior of the poultry workers and consequently translates into dissatisfaction with the job. Besides, every rational being makes rational choices, so if there is a marginal increase in pay at the workplace the motivation to work hard is observed as low vis-à-vis a substantial pay increase. The result is at odds with the empirical finding of Ellickson and Logsdon, (2002) and Chaudhry et al. (2011) who found a positive relationship between salary (pay) and job satisfaction.

Further, relationships with co-workers are positive and significant $(\mathrm{p}<5 \%)$. This reveals that as relationships with coworkers increase the propensity of the poultry worker being satisfied with the job is more likely to increase by $37 \%$. The plausible justification could be that at the job site the poultry workers could engage in a conversation with co-workers to release stress and as this continues emotional bondage is created. This bondage created proliferates job satisfaction since a sense of companion is felt between both parties. However, the results corroborate the findings of Čábelková et al. (2015) who revealed that relationship at the workplace has a positive influence on job satisfaction. Moreover, the result was in line with the empirical findings of Sowmya and Panchanatham, (2011) and Asegid et al. (2014) who revealed that the behavior of co-workers and group cohesion was a significant determinant of job satisfaction.

\section{Hypothesis testing}

Decision rule based on P-value:

If $\mathrm{P} \leq \alpha$, reject $\mathrm{H}_{0}$. If $\mathrm{P}>\alpha$, fail to reject $\mathrm{H}_{0}$. Significance level at $5 \%$

From table 3, the P-value of pay was 0.003 . Indicating that, $0.003 \leq 0.05$

Therefore, the null hypothesis is rejected in favor of the alternative, as there is sufficient evidence to indicate that the null hypothesis claim is false. Intrinsically, it is interesting to note that, based on equity theory, if poultry workers are satisfied with their pay, they would want to stay longer compared to referent others who are not satisfied.

Table 4: Reaction to Inequity after Comparing Input-Output to Referent Others

\begin{tabular}{lcc}
\hline Equity sensitivity category & $\begin{array}{c}\text { Frequency } \\
\text { (No) }\end{array}$ & $\begin{array}{c}\text { Percentage } \\
(\%)\end{array}$ \\
\hline Benevolent & 52 & 52 \\
Equity sensitive & 28 & 28 \\
Entitled & 20 & 20 \\
\hline
\end{tabular}

Source: Field Survey, 2020. 
Inequity results when the input-output ratio of an individual compared to the input-output ratio of others in similar working conditions are not equal. From table 4, 52\% of the poultry workers indicated that they are "Content with the working environment" after sensing inequity in the organization. Moreover, $28 \%$ of the poultry workers reported that they would "Negotiate for a salary commensurate to their skills" and $20 \%$ of the poultry workers claimed they would "Negotiate for a raise in salary" or "Reduce input". Indicating that, there is dominance $(52 \%)$ of benevolent poultry workers in the poultry sub-sector of the study area. At the same time, the proportion of equity sensitive poultry workers was $28 \%$ whereas $20 \%$ is entitled. The proportion classified as benevolent would always bring forth their full capacity at work regardless of pay, the entitled often strive for an increase in pay while the equity sensitive is fair and transparent poultry workers.

\section{CONCLUSION AND RECOMMENDATION}

The study examined the determinants of job satisfaction amongst employees in the poultry sub-sector of Ghana; a test of equity theory using data from 100 poultry workers. The determinants of job satisfaction were estimated using the logistic regression model. The logit model estimation reveals that job satisfaction is influenced by occupational level, pay, and relationships with co-workers. However, relationships with co-workers (1.4866) had an enormous effect. Indicating the pragmatic significance of relationships with co-workers on job satisfaction.

Also, the empirical findings revealed that the poultry sub-sector is predominated with benevolent poultry workers, followed by equity sensitive and entitled poultry workers. The preponderance of benevolent poultry workers suggests that the poultry industry can not entirely work with workers classified as equity sensitive and entitled. Based on the empirical findings of the study, owners and managers of poultry farms should consider relationships with co-workers as key to job satisfaction amongst the poultry workers. Moreover, a pay increment should be substantial to facilitate satisfaction with the job. It is further recommended that owners and managers of poultry farms should assign a few tasks to the poultry worker when there is a change in the occupational level. Adapting to this recommendation is likely to increase job satisfaction at the workplace. Notwithstanding, the impact of equity theory on workers in the cocoa value chain could also be investigated as cocoa remains a staple crop in Ghana.

\section{ACKNOWLEDGEMENT}

We express our sincere gratitude to Amprofi Ampah Amproche a geospatial analyst for his immense contribution to the construction of the study area map. Again, we say your contribution to the manuscript was one of a kind.

\section{REFERENCES}

Adams, J. S. (1963): Towards an understanding of inequity. The Journal of Abnormal and Social Psychology; 67(5): 422436 Permanent link to this document: https://doi.org/10.1037/ h0040968

Aggarwal, U., Bhargava. S., (2010): The Effects of Equity Sensitivity, Job Stressors and Perceived Organisational Support on Psychological Contract Breach. Vision, Vol. 14 Iss 1-2 pp. 45-55.

Allen, R. S., Evans, W. R., White, C. S., (2011): Affective organizational commitment and organizational citizenship behavior: examining the relationship through the lens of equity sensitivity. Organization Management Journal, Vol. 8 Iss 4 pp. 218-228.

Allen, R. S., Takeda, M., White, C. S., (2005): Cross-cultural equity sensitivity: a test of differences between the United States and Japan. Journal of Managerial Psychology, Vol. 20 Iss. 8 pp. 641-662.

Allen, R. S., White, C. S., (2002): Equity sensitivity theory: A test of responses to two types of under-reward situations. Journal of managerial issues, Vol. 14 Iss. 4 pp. 435-451.

Amissah, E. F., Gamor, E., Deri, M. N., Amissah, A., (2016): Factors influencing employee job satisfaction in Ghana's hotel industry. Journal of Human Resources in Hospitality \& Tourism, Vol. 15 Iss. 2, pp. 166-183.

Amoabeng, E. (2011): Financial management knowledge among entrepreneurs in the poultry industry: a case of the Dormaa municipality (Doctoral dissertation). Institute of distance learning Kwame Nkrumah University of Science and Technology.

Artz, B. (2010): The impact of union experience on job satisfaction. Industrial Relations: A Journal of Economy and Society; 49(3): 387-405.

Asegid, A., Belachew, T., Yimam, E., (2014): Factors influencing job satisfaction and anticipated turnover among nurses in Sidama zone public health facilities, South Ethiopia. Nursing research and practice, Vol. 2014 Iss. 909768 pp. 1-26 Permanent link to this document: https://doi.org/10.1155/2014/909768

Bannor, R. K., Abele, S., Kuwornu, J. K., Oppong-Kyeremeh, H., Yeboah, E. D., (2020): Consumer segmentation and preference for indigenous chicken products. Journal of Agribusiness in Developing and Emerging Economies. Permanent link to this document: https://doi.org/10.1108/JADEE-08-2020-0162

Bender, K. A., Heywood, J. S., (2006): Job satisfaction of the highly educated: The role of gender, academic tenure, and earnings. Scottish Journal of Political Economy, Vol. 53 Iss. 
2 pp. 253-279 Permanent link to this document: https://doi. org/10.1111/j.1467-9485.2006.00379.x

Bolino, M. C., Turnley, W. H., (2008): Old faces, new places: Equity theory in cross\cultural contexts. Journal of Organizational Behavior: The International Journal of Industrial, Occupational and Organizational Psychology and Behavior, Vol. 29 Iss. 1 pp. 29-50 Permanent link to this document: https://doi.org/10.1002/job.454

Čábelková, I., Abrhám, J., Strielkowski, W., (2015): Factors influencing job satisfaction in post-transition economies: the case of the Czech Republic. International Journal of Occupational Safety and Ergonomics, Vol. 21 Iss. 4, pp. 448456 Permanent link to this document: https://doi.org/10.1080 /10803548.2015.1073007

Chaudhry, M. S., Sabir, H. M., Rafi, N., Kalyar, M. N., (2011): Exploring the Relationship between Salary Satisfaction and Job Satisfaction: A Comparison of Public and Private Sector Organizations. Journal of Commerce, Vol. 3 Iss. 4 pp. 1-14.

Dugguh, S. I., Dennis, A., (2014): Job satisfaction theories: Traceability to employee performance in organizations. IOSR journal of business and management, Vol. 16 Iss. 5 pp. 11-18.

Ellickson, M. C., Logsdon, K., (2002): Determinants of job satisfaction of municipal government employees. Public Personnel Management, Vol. 31 Iss. 3 pp. 343358 Permanent link to this document: https://doi. org $/ 10.1177 / 009102600203100307$

GSS (Ghana Statistical Service)., (2014): 2010 Population and housing census. district analytical report.

Hoetker, G. (2007): The use of logit and probit models in strategic management research: Critical issues. Strategic Management Journal; 28(4): 331-343 Permanent link to this document: https://doi.org/10.1002/smj.582

Karatepe, O. M., Avci, T., Karatepe, T., Canozer, S., (2003): The measurement of job satisfaction: an empirical study of frontline employees in the Northern Cyprus hotel industry. International Journal of Hospitality \& Tourism Administration, Vol. 4 Iss1 pp. 69-85 Permanent link to this document:https://doi.org/10.1300/J149v04n01_04

Kingsley Westerman, C. Y. (2013): How people restore equity at work and play: Forgiveness, derogation, and communication. Communication Studies; 64(3): 296-314 Permanent link to this document:https://doi.org/10.1080/10510974.2012.755641

Kingsley Westerman, C. Y., Park, H. S., Lee, H. E., (2007): A test of equity theory in multidimensional friendships: A comparison of the United States and Korea. Journal of Communication, Vol. 57 Iss. 3 pp. 576-598 Permanent link to this document: https://doi.org/10.1111/j.1460-2466.2007.00358.x
Kollmann, T., Stöckmann, C., Kensbock, J. M., Peschl, A., (2019): What satisfies younger versus older employees, and why? An aging perspective on equity theory to explain interactive effects of employee age, monetary rewards, and task contributions on job satisfaction. Human Resource Management, Vol. 59 Iss 1 pp. 101-115 Permanent link to this document: https://doi.org/10.1002/hrm.21981

Lapidus, R. S., Pinkerton, L., (1995): Customer complaint situations: An equity theory perspective. Psychology \& Marketing, Vol. 12 Iss. 2, pp. 105-122 Permanent link to this document: https://doi.org/10.1002/mar.4220120203

Lee, R., Mueller, L. B., Miller, K. J., (1981): Sex, wageearner status, occupational level, and job satisfaction. Journal of vocational behavior, Vol. 18 Iss. 3 pp. 362-373 Permanent link to this document: https://doi.org/10.1016/00018791(81)90022-1

Lovegrove, H., Fairley, S., (2017): Using equity theory to understand non-host city residents' perceptions of a megaevent. Journal of Sport \& Tourism, Vol. 21 Iss. 1 pp. 1-14 Permanent link to this document:https://doi.org/10.1080/147 75085.2016.1254108

Mensah, N. O., Amrago, E. C., Asare, J. K., Tutu, F. O., Donkor, A., (2020): Poultry farmers willingness to pay for agricultural tax: evidence from the Bono region, Ghana. World Journal of Entrepreneurship, Management and Sustainable Development. Permanent link to this document:https://doi. org/10.1108/WJEMSD-04-2020-0037

Metle, M. A. K. (2001): Education, job satisfaction and gender in Kuwait. International Journal of Human Resource Management; 12(2): 311-332 Permanent link to this document: https://doi.org/10.1080/09585190122366

Mudrack, P. E., Mason, E. S., Stepeanski, K. M., (1999): Equity sensitivity and business ethics. Journal of Occupational and Organizational Psychology, Vol. 72 Iss. 4 pp. 539-560 Permanent link to this document:https://doi. org/10.1348/096317999166833

Oren, L., Littman-Ovadia, H., (2013): Does equity sensitivity moderate the relationship between effort-reward imbalance and burnout. Anxiety, Stress \& Coping, Vol. 26 Iss. 6 643658 Permanent link to this document: https://doi.org/10.108 $0 / 10615806.2012 .753060$

Oshagbemi, T. (2003): Personal correlates of job satisfaction: empirical evidence from UK universities. International journal of social economics, Vol. 30 Iss. 12 pp. 1210-1232 Permanent link to this document: https://doi. org $/ 10.1108 / 03068290310500634$

Owusu-Sekyere, A. (2011): The Contribution of Agricultural Development Bank (ADB) to the Growth of the Poultry Sector: 
A Case Study of Dormaa Municipality (Doctoral dissertation). Kwame Nkrumah University of Science and Technology.

Rana, S., Agrawal, P., (2016): Factors Influencing Job Satisfaction of Academicians in Indian Context. International Journal of Advanced Research in Management Engineering Technology, Vol. 1 Iss. 5 pp. 228-238.

Sowmya, K. R., Panchanatham, N., (2011): Factors influencing job satisfaction of banking sector employees in Chennai, India. Journal of law and conflict Resolution, Vol. 3 Iss. 5, pp. 76-79 Permanent link to this document: https:// doi.org/10.5897/JLCR.9000014

Taherdoost, H. (2016): Sampling methods in research methodology; How to choose a sampling technique for research. Permanent link to this document:http://dx.doi. org $/ 10.2139 /$ ssrn. 3205035

Tarcan, M., Hikmet, N., Schooley, B., Top, M., Tarcan, G. Y., (2017): An analysis of the relationship between burnout, socio-demographic and workplace factors and job satisfaction among emergency department health professionals. Applied nursing research, Vol. $34 \mathrm{pp}$. 40-47 Permanent link to this document: https://doi.org/10.1016/j.apnr.2017.02.011

Tinuoye, G. O. O., Omeluzor, S. U., Akpojotor, L. O., (2016): Factors influencing job satisfaction of academic librarians in university libraries in Edo and Delta states, Nigeria. The Electronic Library, Vol. 34 Iss 6 pp. 985-996 Permanent link to this document: https://doi.org/10.1108/EL-07-2015-0128

Van Mourik, C. (2014): The equity theories and the IASB conceptual framework. Accounting in Europe; 11(2): 219-233 Permanent link to this document: https://doi.org/10.1080/174 49480.2014.949278

Yamane, T. (1967): Statistics: An Introductory Analysis, 2nd ed., Harper and Row, New York. 